\title{
THE INFLUENCE OF INNOVATIVENESS, RISK TAKING, AND PROACTIVENESS TOWARD SOCIAL ENTERPRISE ECONOMIC PEFORMANCE IN SURABAYA
}

\author{
Lila Ramadhani Sukendy, Wendra Hartono \\ Universitas Ciputra Surabaya
}

\begin{abstract}
This research analyzes the influence of innovativeness, risk taking and proactiveness towards social enterprise economic performance in Surabaya. The researcher uses simple random sampling method to collect the data. The data was collected by handing out questionnaires with a fivepoint Likert scale and there are 32 social enterprises in Surabaya who participated in this study. The data analysis process was done by using the statistical program SPSS 22. Through this research, it was found that innovativeness has a significant influence towards economic performance $($ sig value $=0.014)$, whereas, risk taking $($ sig value $=0.086)$ and proactiveness $($ sig value $=0.900)$ do not influence economic performance significantly. Innovativeness, risk taking and proactiveness have a significant and simultaneous effect towards social enterprise economic performance in Surabaya with a significance value of 0.000 . The researcher concludes that $42.8 \%$ of the change happen in economic performance can be explained by innovativeness, risk taking, and proactiveness, while $57.2 \%$ are variables that are still left to be explored. This result may vary in different sample across different country and region.
\end{abstract}

Keywords: social enterprise, innovativeness, risk taking, proactiveness, and economic performance.

\section{INTRODUCTION}

Social enterprise is a business that is classified between donation based nonprofit and profit-maximizing business. The purposes of social enterprise are improving lives and contributing positive change around the world. Social Enterprise puts equality at the core of its business and social mission. The

\footnotetext{
*Corresponding Author.

e-mail: Lrsukendy@gmail.com
} 
difference between entrepreneurship and social entrepreneurship lies in the value proposition. Entrepreneur organizes his value proposition to serve the markets and to create economic profit while the social entrepreneur anticipates and organizes his action in order to create important benefits for society (Martin \& Osberg, 2007). The population of social enterprise in the world is not mass enough but it is significantly growing all around the world.

In Indonesia, the opportunities for social enterprise to grow is significantly high. $64 \%$ of Indonesian consumers are willing to pay extra for brands that are committed to make a positive or social and environmental impact (Nielsen, 2014). Therefore, the number of social enterprises in Indonesia in the last year is growing significantly. Social enterprise economic impact towards Indonesia's Gross Domestic Product (GDP) is worth approximately $\$ 19.6$ billion USD, or $1.9 \%$ of Indonesia's GDP (Gregory et al., 2018). The number of full-time workers employed by social enterprises increased by 42\% from 2016 to 2017 (Gregory et al., 2018). This growth rate is higher than the year-on-year growth rate of full-time employment in MSMEs, which only increase by $5.9 \%$, over the same period (Direktorat Pengembangan UKM dan Koperasi, 2016).

Social enterprises only contribute a small part of Indonesia's economy, but its significant growth and impact are impressive, especially compared to traditional enterprise. This business model could be the answer to overcome poverty, unequal distribution of wealth, environmental issue, and other crucial issues in Indonesia. In order for social enterprise to resolve more problem, social enterprise needs to grow. In Indonesia, only 454 out of 1,400 aspiring SEs are categorized as social enterprise. Aspiring SEs are businesses that may have not meet the criteria of SE (Yulius et al., 2015).

Related to social enterprises' growth and development, social entrepreneurs in Indonesia are facing several difficulties. Problem related to funding is the main challenges faced by social enterprises. Lack of capital restrains the social enterprises to create social and environmental impact. A lot of social enterprises are not invest-ready because those social enterprises have limited likelihood to generate profit and returns (Angin, 2016). Only a few of Indonesian social enterprises can generate enough value creation (profit and return expectation) to be funded by impact investors (Angin, 2016). 
Social enterprises' primary goal is to generate social value. At the same time, social enterprises are market-oriented enterprise that need to pursue goals in an entrepreneurial manner and to generate their own revenues to sustain themselves (Vijverman, 2014). In contrary with other nonprofit voluntary organizations, social enterprises are enterprises and their social goals can be reached only by considering their economic efficiency (Bagnoli \& Megali, 2011, in, Marika, Giovanni, \& Mario, 2016).

It is crucial to identify any internal factors that influence the economic performance of social enterprises to obtain further implications to develop social entrepreneurship sector, as it may bring positive forces for social and economic development in Indonesia. Based on the pre-survey participated by 10 social entrepreneurs which currently in operation stage, there are three most voted factors that influence economic performance. The factors are innovativeness, risk-taking and proactiveness. Based on the factors explained, the researcher decides to examine the direct influence of innovativeness, risk taking and proactiveness towards the economic performance of social enterprise.

\section{METHOD}

\section{Research Type, Population and Sampling}

This research type is quantitative. Quantitative research examines the relationship between variables, which are measured numerically and analyzed using a range of statistical and graphical techniques (Saunders et al., 2016). In this research, the targeted population is social enterprise located in Surabaya. Based on PLUS's social enterprise data, there are 35 social enterprises located in Surabaya. PLUS is a collaborative space for the social impact ecosystem in Indonesia to connect, learn, collaborate and create more meaningful impact to community and environment (PLUS, 2019).

The sampling method used in this research is based on probability sampling. In probability sampling, the probability of each case is being selected from the target population and is equal for all cases (Saunders et al., 2016). Probability sampling provide estimation of precision and offer the opportunity to generalize the findings to the population of interest from the sample population (Cooper 
$\&$ Schindler, 2014). The techniques used is simple random sampling. In a simple random sampling, each item or person in the population has the same chance of being selected (Cooper \& Schindler, 2014). The number of samples was determined using Slovin technique with 5\% error margin, which results in 33 samples.

\section{Data Collection Procedure}

To collect the data, the researcher distributed self-completed online (Google Form) and offline questionnaires to 35 social enterprise in Surabaya. Questionnaire is one of the method of data collection in which each person is asked to respond to the same set of questions in a predetermined order (Cooper \& Schindler, 2014). The questionnaire is translated to Bahasa to reduce the risk of misconception and misunderstanding because of language barrier.

\section{Analysis Methods}

The researcher uses multiple linear regression analysis to know the impact or the linear relationship between two or more independent variables towards one dependent variable (Knapp, 2017). The equation of the multiple linear regression is as follow:

$$
Y=\beta_{\%} X_{\%}+\beta_{(} X_{(}+\beta_{)} X_{)}+e
$$

Description:

Y: Economic performance

$\beta_{\%}, \beta, \beta$ : Regression coefficient

$\mathrm{X} 1$ : Innovativeness

$\mathrm{X} 2$ : Risk taking

X3: Proactiveness

e: Error

\section{RESULTS}

\section{Respondent and Social Enterprise Characteristic}

Out of 32 respondents, $53.13 \%$ are male respondents and $46.88 \%$ are female respondents. $63 \%$ of the participants are in the age of 18-26 years old, 
$31 \%$ are in the age of $27-35$ years old and $6 \%$ are in the age of 36 years old or older. The social enterprises that participated in this study are mostly established in 2017. 34\% of the social enterprises address environmental issue, $25 \%$ address community empowerment, $16 \%$ address education issue and $25 \%$ address other issues not mentioned on the questionnaire options.

\section{Validity Test}

The validity test is determined by the Pearson Correlation analysis. If all of the sig.value of the Pearson Correlation is $\leq 0.05$, the indicators on the questionnaires are valid (Cooper $\&$ Schindler, 2014). The data shows that every indicator has a value less than 0.05 . Based on the result, the researcher concluded that all the indicator is valid.

Table 1 Validity Test Result

\begin{tabular}{lccc}
\hline \multicolumn{1}{c}{ Variable } & $\begin{array}{c}\text { Pearson } \\
\text { Correlation }\end{array}$ & Sig. (2-tailed) & Conclusion \\
\hline Innovativeness & & & \\
X1.1 & 0.749 & 0.000 & Valid \\
X1.2 & 0.812 & 0.000 & Valid \\
X1.3 & 0.814 & 0.000 & Valid \\
Risk Taking & & & \\
X2.1 & 0.864 & 0.000 & Valid \\
X2.2 & 0.715 & 0.000 & Valid \\
X2.3 & 0.816 & 0.000 & Valid \\
Proactiveness & & & \\
X3.1 & 0.826 & 0.000 & Valid \\
X3.2 & 0.656 & 0.000 & Valid \\
X3.3 & 0.887 & 0.000 & Valid \\
Economic Performance & & & \\
Y1.1 & 0.606 & 0.000 & Valid \\
Y1.2 & 0.721 & 0.000 & Valid \\
Y1.3 & 0.791 & 0.000 & Valid \\
Y1.4 & 0.811 & 0.000 & Valid \\
Y1.5 & 0.826 & 0.000 & Valid \\
Y1.6 & 0.577 & 0.001 & Valid \\
\hline
\end{tabular}




\section{Reliability Test}

The method used by the researcher to analyze the reliability of this research is Cronbach Alpha. The reliability is acceptable when the alpha value is larger and/or equal to 0.7 (Cooper \& Schindler, 2014). The data shows that every indicator has a value larger and/or equal to 0.07 . Based on the result, the researcher concluded that all the indicator is reliable.

Table 2 Reliability Test Result

\begin{tabular}{lcc}
\hline \multicolumn{1}{c}{ Variable } & Cronbach's Alpha & Conclusion \\
\hline Innovation & 0.703 & Reliable \\
Risk Taking & 0.715 & Reliable \\
Proactiveness & 0.708 & Reliable \\
Economic Performance & 0.821 & Reliable \\
\hline
\end{tabular}

\section{Multicollinearity Test}

Multicollinearity appears when two or more independent variables in the regression model are correlated. The value of VIF (variance inflation factors) have to be $<10$, which implicates that there is no multicollinearity (Daoud, 2017). The value of the VIF of every variable is less than 10 , which mean there is no multicollinearity in the research data.

Table 3 Multicollinearity Test Result

\begin{tabular}{lll}
\hline \multirow{2}{*}{ Model } & \multicolumn{2}{c}{ Collinearity Statistics } \\
\cline { 3 - 3 } & \multicolumn{3}{c}{ VIF } \\
\hline \multirow{2}{*}{1} & (Constant) & \\
& X1.A & 1.660 \\
& X2.A & 1.691 \\
& X3.A & 1.908 \\
\hline
\end{tabular}

\section{Normality Test}

The normality test is conducted by Kolmogorov-Smirnov. When the sig value is $\geq 0.05$, it implicates that the data has a normal distribution (Das \& Imon, 
Lila Ramadhani Sukendi, Wendra Hartono / The Influence of Innovativeness, Risk Taking Proactiveness toward Social Enterprise Economic Performance in Surabaya

2016). In this research, the sig value is 0.200 , which implicates that the data has a normal distribution.

Table 4 Normality Test Result

\begin{tabular}{lll}
\hline \multicolumn{1}{c}{$\mathbf{N}$} & \multicolumn{2}{c}{ Instandardized Residual } \\
& \multicolumn{2}{c}{32} \\
\hline Normal Parameters ${ }^{\mathrm{a}, \mathrm{b}}$ & $\begin{array}{l}\text { Mean } \\
\text { Std. }\end{array}$ & .0000000 \\
& Deviation & \\
& Absolute & .11563093 \\
Most Extreme & Positive & .105 \\
Differences & Negative & -.110 \\
& & .110 \\
Test Statistic & & $.200^{\mathrm{c,d}}$ \\
Asymp. Sig. (2-tailed) & & \\
\hline
\end{tabular}

\section{Heteroskedasticity Test}

The heteroskedasticity test is conducted using Glejser test. When the sig value is $>0.05$, it implicates that the residual variance has no heteroscedasticity (Wiedermann et al., 2017). In this research, the sig value is $0.057,0.598$, and 0.583 , which implicates that the data has no heteroskedasticity.

Table 5 Heteroskedasticity Test Result

\begin{tabular}{|c|c|c|c|c|}
\hline & Model & $\begin{array}{c}\text { Standardized Coefficients } \\
\text { Beta }\end{array}$ & $\mathbf{t}$ & Sig. \\
\hline 1 & (Constant) & & .133 & .895 \\
\hline & X1.A & .452 & 1.987 & .057 \\
\hline & X2.A & -.123 & -.534 & .598 \\
\hline & X3.A & -.135 & -.555 & .583 \\
\hline
\end{tabular}

\section{Linearity Test}

Two variables have a linear relationship if the significance value is more than 0.05 (Cooper \& Schindler, 2014). In this research, the sig value is $0.971,0.764$ and 0.881 , which implicates that the data has a linear relationship. 
Journal of Accounting, Entrepreneurship, and Financial Technology

Volume 02, Number 01, October 2021

Table 6 Linearity Test Result

\begin{tabular}{|c|c|c|c|c|}
\hline & & & $\mathbf{F}$ & Sig. \\
\hline \multirow[t]{6}{*}{ Y1.A. * X1.A } & Between Groups & (Combined) & 2.323 & .054 \\
\hline & & Linearity & 16.907 & .000 \\
\hline & & Deviation from & .239 & .971 \\
\hline & & Linearity & & \\
\hline & Within Groups & & & \\
\hline & Total & & & \\
\hline \multirow[t]{6}{*}{ Y2.A. * X2.A } & Between Groups & (Combined) & 2.126 & .075 \\
\hline & & Linearity & 12.943 & .002 \\
\hline & & Deviation from & .581 & .764 \\
\hline & & Linearity & & \\
\hline & Within Groups & & & \\
\hline & Total & & & \\
\hline \multirow[t]{6}{*}{ Y3.A. * X3.A } & Between Groups & (Combined) & 1.382 & .256 \\
\hline & & Linearity & 8.128 & .009 \\
\hline & & Deviation from & .418 & .881 \\
\hline & & Linearity & & \\
\hline & Within Groups & & & \\
\hline & Total & & & \\
\hline
\end{tabular}

\section{Multiple Linear Regression Analysis}

The equation of the multiple linear regression is as follow:

Description:

$$
Y=0.459 X_{\%}+0.314 X_{(}+0.024 X_{)}
$$

Y: Economic performance of social enterprise

$\mathrm{X} 1$ : Innovativeness

X2: Risk taking X3: Proactiveness

Table 7 Regression Test Result

\begin{tabular}{|c|c|c|c|c|}
\hline \multirow{2}{*}{\multicolumn{2}{|c|}{ Model }} & $\begin{array}{c}\text { Standardized } \\
\text { Coefficients }\end{array}$ & \multirow[t]{2}{*}{$\mathrm{t}$} & \multirow[t]{2}{*}{ Sig. } \\
\hline & & Beta & & \\
\hline 1 & (Constant) & & 1.730 & .095 \\
\hline & X1.A & .459 & 2.622 & .014 \\
\hline & $\mathrm{X} 2 . \mathrm{A}$ & .314 & 1.777 & .086 \\
\hline & X3.A & .024 & .127 & .900 \\
\hline
\end{tabular}

The researcher uses standardized coefficients instead of unstandardized coefficient to assess the variable that has the highest impact with the outcome 
variable (Anaya et al., 2015). The positive value of innovativeness, risk taking, and proactiveness indicates that each variable has a positive relationship with the dependent variable.

\section{Simulant Significance Test (F Test)}

When the $F$ value $\leq 0.05$, it implicates that the independent variables have a simultaneous significant effect towards the dependent variable (Cooper \& Schindler, 2014). The significance value in this research is 0.000 . The result shows that innovativeness, risk taking, and proactiveness simultaneously influence economic performance.

Table 8 F Test Result (ANOVA ${ }^{a}$ )

\begin{tabular}{llrrrrr}
\hline Model & $\begin{array}{c}\text { Sum of } \\
\text { Squares }\end{array}$ & df & $\begin{array}{c}\text { Mean } \\
\text { Square }\end{array}$ & F & Sig. \\
\hline 1 & Regression & 5.002 & 3 & 1.667 & 8.718 & $.000^{\mathrm{b}}$ \\
& Residual & 5.355 & 28 & .191 & & \\
Total & 10.358 & 31 & & & \\
\hline
\end{tabular}

\section{Partial Significance Test (t Test)}

When the $\mathrm{t}$ value is $\leq 0.05$, it implicates that the independent variable partially affects the dependent variable significantly. If the value is greater than 0.05 , it suggests that statistically, there is no significant difference between the variance of one group and the other group (Knapp, 2017). In this research, the significance value of innovativeness is 0.014 , risk taking is 0.086 , and proactiveness is 0.900 . Therefore, innovativeness has a significance influence toward economic performance, whereas risk taking and proactiveness does not influence economic performance.

Table $9 \mathrm{t}$ Test Result (ANOVA ${ }^{\mathrm{a}}$ )

\begin{tabular}{llcccc}
\hline \multirow{2}{*}{ Model } & Standardized Coefficients & \multirow{2}{*}{ T } & Sig. & $\frac{\text { Collinearity Statistics }}{\text { Bota }}$ \\
\cline { 3 - 5 } 1 & (Constant) & & 1.730 & .095 & Tolerance \\
X1.A & .459 & 2.622 & .014 & .603 \\
X2.A & .314 & 1.777 & .086 & .591 \\
X3.A & .024 & .127 & .900 & .524 \\
\hline
\end{tabular}




\section{Coefficient of Correlation (R) and Coefficient of Determination $\left(\mathrm{R}^{2}\right)$}

When the $\mathrm{R}$ value is close to 1 , it implicates that the correlation is stronger (Cooper \& Schindler, 2014). In this research, the coefficient of correlation (R) value is positive and close to 1 (0.695), which indicates that the correlation between the variables is strong. As one variable increases, the other variable will also increase.

The Coefficient of Determination $\left(\mathrm{R}^{2}\right)$ is used to measure the amount of common variance between the independent and the dependent variable (Cooper \& Schindler, 2014). The value of $\mathrm{R}^{2}$ is 0.428 or $42.8 \%$ which implicates that $42.8 \%$ of the change happening in economic performance can be explained or associated with the change of innovativeness, risk taking, and proactiveness.

Table $10 \mathrm{R}$ and $\mathrm{R}^{2}$ Test Result (Model Summary ${ }^{\mathrm{b}}$ )

\begin{tabular}{ccccc}
\hline Model & $\mathrm{R}$ & R Square & $\begin{array}{c}\text { Adjusted } \\
\text { R Square }\end{array}$ & Std. Error of the Estimate \\
\hline 1 & $.695^{\mathrm{a}}$ & .483 & .428 & .437330426936984 \\
\hline
\end{tabular}

\section{DISCUSSION}

According to the partial significance test ( $t$ Test), the value of innovativeness is 0.014 , which imply that innovativeness has a significant influence towards the economic performance of social enterprises in Surabaya. Therefore, hypothesis 1 (H1) is accepted. This result is supported by Semrau et al. (2016) research in the context of small and medium enterprises. It proves that innovativeness significantly influence enterprise performance across all countries, which considerably vary across the national contexts of the study sample. Based on Hughes \& Morgan (2007) innovativeness significantly impact product performance and customer performance. Ryeowon Lee et al. (2017) also prove that radical product innovation activity and incremental product innovation activity will have positive impacts on a firms' performance. Based on McGee \& Peterson (2017) innovativeness benefited young firms, however this relationship became increasingly negative as the firms aged.

The value of proactiveness is 0.086 , which imply that risk taking does not significantly influence economic performance of social enterprises in Surabaya. Therefore, hypothesis $2(\mathrm{H} 2)$ is rejected. This result is supported by Miles et al. 
Lila Ramadhani Sukendi, Wendra Hartono / The Influence of Innovativeness, Risk Taking Proactiveness toward Social Enterprise Economic Performance in Surabaya

(2013) who prove that entrepreneurial orientation, which consist of innovativeness, risk taking, and proactiveness, does not have a significance impact towards social enterprise economic performance in the case of Australian social enterprise. Based on McGee \& Mark Peterson (2017), risk taking has a stronger positive impact on younger firms compared to older firms. This result is also contradictory with another research in commercial firm context which stated that risk taking is an integral entrepreneurial function that can lead to success (Brockhaus, 1980). Based on Semrau et al. (2016), risk taking significantly influences small and medium enterprise performance across all countries, which considerably vary across the national contexts in the study sample. Another research conducted in India by John (2016) proves that there are 13 critical success factors of social enterprise, which includes risk taking.

According to the partial significance test ( $t$ Test), the value of proactiveness is 0.900 , which imply that proactiveness does not significantly influence economic performance of social enterprise in Surabaya. Therefore, hypothesis 3 (H3) is rejected. This result is supported by Miles et al. (2013) who proves that entrepreneurial orientation, which consist of innovativeness, risk taking, and proactiveness, does not have a significance impact towards social enterprise economic performance in the case of Australian social enterprise. Based on McGee and Peterson (2017), proactiveness were relatively more beneficial for older firms. In contrary, small and medium enterprises found proactiveness to be significantly influence the enterprises' performance across all countries, which considerably vary across the national contexts in the study sample (Semrau et al., 2016). Another research conducted by John (2016) find that there are 13 critical success factors of social enterprise including proactiveness.

The positive value of innovativeness, risk taking and proactiveness in the linear regression equation (0.459) indicates that innovativeness, risk taking and proactiveness has a positive relationship with economic performance. As the independent variables increase by value, it will increase social enterprises' economic performance in context of Surabaya's social enterprise. Even though proactiveness and risk taking does not significantly affect economic performance, along with innovativeness and risk taking, proactiveness show a significant effect towards social enterprises' economic performance. This result shows that proactiveness still need to be considered as a factor that supports the economic performance of social enterprises in Surabaya. 


\section{Conclusion and Limitation}

The researcher concludes that innovativeness significantly influences social enterprise economic performance in Surabaya, whereas, risk taking and proactiveness does not significantly influence social enterprise economic performance in Surabaya. The result may vary in different sample across different country and region.

Social enterprises are suggested to attain commercial business strategies and practices. However, the relevancy of existing theories and strategies in the context of social enterprises have not been studied enough compared to studies on commercial firms (Bhattarai et al., 2019). Therefore, future research should address theories and strategies that is relevant in social enterprise context.

The perceptions of an entrepreneur may or may not be compatible with other entrepreneurs even from the same industry of social enterprise. It will be beneficial if there is a general performance measurement that assess social enterprises' performance economically, socially or based on other aspects with less perceptual bias.

As economic performance increases, it will be beneficial to empirically analyze the effect of increased economic performance towards social performance in the context of social enterprises. Future studies should classified social enterprises based on their sector, size, establishment year or other categories. Similar studies could be also benefit from having a larger sample that represents larger population of social enterprises in different country or region.

The researcher acknowledged that subjective economic performance assessment may have some perceptual bias. Some social entrepreneurs may have different assessment for their enterprise's economic performance; it might be better or worse than other social entrepreneur's assessment. The perceptions of entrepreneurs may or may not be compatible with others entrepreneurs within the same industry (McGee \& Peterson, 2017).

In this study, the researcher uses a general definition of social enterprises and did not considered the social enterprises' sector, size, establishment year or other categories. The sample size is also relatively small, thus, the research result might not be applicable to different social enterprises in different region. From 33 social enterprise, only 32 social enterprise taken as the sample because there is 1 social enterprise data that have an extreme data value which must be eliminated. 
Lila Ramadhani Sukendi, Wendra Hartono / The Influence of Innovativeness, Risk Taking Proactiveness toward Social Enterprise Economic Performance in Surabaya

\section{REFERENCES}

Anaya, C., Torrent, C., Caballero, F. F., \& Vieta, E. (2015). Cognitive Reserve in Bipolar Disoder. Acta Psychiatrica Scandinavica.

Angin. (2016). Social Finance and Social Enterprises: A New Frontier of Development in Indonesia. Jakarta: UNDP.

Bagnoli, L. \& Megali, C. (2011). Measuring performance in social enterprise. Nonprofit and Voluntary Sector, 151.

Bhattarai, C. R., Kwong, C. C., \& Tasavori, M. (2019). Market orientation, market disruptiveness capability and social enterprise performance: An empirical study from the United Kingdom. Journal of Business Research.

Brigham, E. F., \& Houston, J. F. (2018). Essentials of Financial Management, Fourth Edition. Singapore: Cengage Learning.

Brockhaus, R. (1980). Risk Taking Prospensity of Entrepreneurs. Academy of Management Journal, 509-520.

Cooper, D. \& Schindler, P. (2014). Business Research Methods. New York: McGraw-Hill. Daoud, J. I. (2017). Multicollinearity and Regression Analysis. Journal of Physics: Conference Series.

Das, K. R. \& Imon, A. R. (2016). A Brief Review of Tests for Normality . American Journal of Theoretical and Applied Statistics, 9.

Dewan Perwakilan Rakyat. (2015). Retrieved from Dewan Perwakilan Rakyat Indonesia: http://dpr.go.id/doksileg/proses2/RJ2-20151210-040422-8650.pdf.

Direktorat Pengembangan UKM dan Koperasi. (2016). Warta KUMKM: Penguatan UMKM untuk Pertumbuhan Ekonomi yang Berkualitas. Jakarta: Bappenas. Gregory, D., Tristan, A., Sutanti, A., \& Indasari, M. P. (2018). Developing an Inclusive and Creative Economy. Jakarta: British Council.

Hughes, M., \& Morgan, R. (2007). Deconstructing the relationship between entrepreneurial orientation and business performance at the embryonic stage of firm growth. Industrial Marketing Management.

Hughes, M., \& Morgan, R. E. (2007). Deconstructing the relationship between entrepreneurial orientation and business performance at the embryonic stage of firm growth. Industrial Marketing Management.

John, M. (2016). A conceptual model of critical success factors for Indian social enterprises. World Journal of Entrepreneurship, Management, and Sustainable Development. 
Knapp, H. (2017). Introductory Statistic Using SPSS. Thousand Oaks: Sage Publication.

Lee, R., Lee, J.-H., \& Garrett, T. (2017). Synergy effects of innovation on firm performance. Journal of Business Research.

Marika, A., Giovanni, A., \& Mario, C. (2016). Indicators and metrics for social business: a review of current approaches. Journal of Social Entrepreneurship.

Martin, R. \& Osberg, S. (2007). Social Entrepreneurship: The Case for Definition. Retrieved from Stanford Social Innovation Review: https://ssir.org/ articles/entry/social_entrepreneurship_the_case_for_definition.

McGee, J. \& Peterson, M. (2017). The long-term impact of entrepreneurial selfefficacy and entrepreneurial orientation on venture performance. Journal of Small Business Management.

Miles, P. M., Verreynne, L. M., Luke, B., Eversole, R., \& Barraket, J. (2013). The Relationship of Entrepreneurial Orientation, Vincentian Values and Economic and Social Performance in Social Enterprise. Review of Business.

Nielsen. (2014). Doing Well by Doing Good. Global Corporate Social Responsibility, 5 .

PLUS. (2019). Community. Retrieved from Usaha Sosial: https://usahasosial.com/ community/map/?wpv-organization-province =jawa-timur- en\&wpv_aux_ current_post_id $=162 \mathrm{xwpv} \_v i e w \_c o u n t=17706$-TCPID16

Saunders, M., Lewis, P., \& Thornhill, A. (2016). Seventh Edition: Research Methods for Business Students. Harlow: Pearson Education Limited.

Semrau, T., Ambos, T., \& Kraus, S. (2016). Entrepreneurial orientation and SME performance across societal culture: An international study. Journal of business research.

Vijverman, N. (2014). Performance of Social Enterprises: An Explorative Analysis. Ghent: Universiteit Gent.

Wales, W. J. (2016). Entrepreneurial orientation: A review and synthesis of promising research directions. International Small Business Journal, 2.

Wiedermann, W., Artner, R., \& Eye, A. V. (2017). Heteroscedasticity as a Basis of Direction Dependence in Reversible Linear Regression Models. Multivariate Behavioral Research.

Yulius, Siregar, H., \& Tampubolon, N. (2015). The Art of Sustainable Giving. Jakarta: Boston Consulting Group. 